ROCZNIKI TEOLOGICZNE

Tom LXVII, zeszyt $1-2020$

DOI: http://dx.doi.org/10.18290/rt20671-7

REV. ANDRZEJ ZWOLIŃSKI

\title{
RELIGIOUSNESS IN THE CONTEXT OF END OF LIFE
}

\begin{abstract}
Awaiting the meeting with God is connected with the person's faith. This is faith, in the strict sense of the word, in life "after" the earthly life, life in the "future world." Such life, which is not merely an extension of the familiar existence, is hard to imagine. This existence is different in its essence. Life on earth continues as an endless sequence of successive moments. Eternity is a new dimension of existence, a new quality, continuous "now." In all contacts with God - in the sacraments, prayer, and meditation - we learn to see Him properly. It is a way of life in eternity already "now," today. Present and eternity do not oppose each other, they do not separate from each other, but they are entangled with each other. Eternal life grows in strength within the time that is given to us.

Entire religious care over the dying person is of equally important significance. Every sick person has a right to receive this care, which is also a way of evangelizing illness, a discovery of the redeeming significance of the suffering and pain of passing away. It involves giving a testimony of love through diaconia (service) and canonia (community formation).
\end{abstract}

Key words: death; belonging to Christ; preparation; meeting.

A discussion about the role of spirituality in medicine has been going on for a long time. Studies show that people who are deeply religious live longer. Faith in God has a clear therapeutic effect and gives surprising results. The health of people who regularly engage in religious practices is more regulated. Going to church fosters good habits and, as a result, improves mood (research value: +131 percent); helps smokers give up their habit (+ 78 percent); increases mobility (+ 54 percent); helps give up alcohol addiction $(+39 \%)$. The average life expectancy of those who do not go to church is 75 ; those who go once a week, 82 , and those who go several times a week, 83. Conclusions are surprising: participation in services affects life expectancy, religion and spiritual experiences protect against cardiovascular diseases, and help heal from serious illnesses. 80 percent of Poles are con-

Rev. Prof. Dr. Hab. ANDRZEj ZwolińsKi - Pontifical University of John Paul II in Krakow; address for correspondence - e-mail: andrzej.zwolinski@upjp2.edu.pl 
vinced that their health improves thanks to prayers by their loved ones ( 83 percent of Americans think similarly).

Regardless of these sociological studies and attempts to understand what influence spirituality has on human health, simple observations reveal immense importance of religious experiences in the last moments of life. The dying, even if they were very distant from religious matters throughout their life, often turn to religion in severe illness, engage in conversations on this topic, and seek to understand their condition and the necessity to pass. A terminal illness allows patients to return to the basic questions related to the truth about themselves and seek the answer to the question: who am I? $\mathrm{Pa}$ tients return to their religious beliefs, sometimes long forgotten, to rebuild their hope of eternal life.

\section{RELIGIOUS IMAGE OF DEATH}

The Sacred Congregation for the Doctrine of the Faith in the letter "Recentes episcoporum Synodi" (May 17, 1979), addressed the issue of a proper understanding of death in the light of the requirements of faith. "The Church affirms that a spiritual element survives and subsists after death, an element endowed with consciousness and will, so that the "human self" subsists. To designate this element, the Church uses the word 'soul,' the accepted term in the usage of Scripture and Tradition. Although not unaware that this term has various meanings in the Bible, the Church thinks that there is no valid reason for rejecting it; moreover, she considers that the use of some word as a vehicle is absolutely indispensable in order to support the faith of Christians."

The Bible does not regard death as something extraordinary. It is not just as the grave - holy or unique. The circumstances of the death and burial of prominent figures from the Old Testament are most often ignored and paid no attention to. Moses was buried in the land of Moab, but "no one knows the place of his burial to this day" (Deut 34:6). It is not his grave that is to be worshiped, but the laws of Yahweh that he preached. The fact that the dead are "unclean" and make others unclean, disqualified them in the domain of worship - it protected Israel from the worship of the dead and un-

\footnotetext{
${ }^{1}$ Sz. Holownia, C. Kalb, "Wiara i medycyna," Newsweek Polska (2003), 49: 72-82.

${ }^{2}$ SACRed Congregation For the Doctrine of the Faith: Letter on Certain Questions Concerning Eschatology, http://www.vatican.va/roman_curia/congregations/cfaith/documents/rc_con _cfaith_doc_19790517_escatologia_en.html_(July 15, 2017).
} 
necessary beautification of death and the dead. According to the Bible, it is a sin to "sit in tombs" (Isa 65:4), to mourn the dead, to worship them or seek their advice (to evoke spirits). An important role was assigned to the words spoken by the dying: blessings (Genesis 48:19-20, 49:8-12, 49:3-7), curses (Gen 9:25-26), or instructions (1 Kings 2:1-9, Deut 33:1), farewells (1 Sm 12) and last wills (Josh. 23).

In the wisdom literature of Israel, death occupied an important place as an element of experience. However, it is treated as a fact that requires no explanation (Prov 10:31): "Remember that we all have to die" (Sir 8:7); "We must indeed die" (2 Sam 14:14). Everyone has a certain number of years to live (seventy or eighty, according to Ps 90:10, or a hundred, according to Sir 18:9), and all these years one should live to the fullest (see Eccles 11:8). The personal character of death emerges as a problem: death is not understood merely as an end of human tasks in general, but also as something happening between God and man; something that separates them. Death puts a seal and confirms separation between man and God. This thought is radicalized in the Old Testament in the idea of Sheol, in which the power of Yahweh over this place is at first not emphasized. Sheol was a fallow, a wasteland, and a sphere of non-existence. In Sheol no one praises God, no one mentions Him after death (cf. Ps 6:6; Isa 28:18; Ps 115:17). God also does not remember those who have been cast into nothingness (Ps 88:5). Death is understood as a result of something that should not have happened and could have been avoided. Death is not part of the essence of a human being, but the result of an act. It does not have a "natural," but a "historical" character (it happened after the original $\sin$ ). ${ }^{3}$

It is only in the context of Christian beliefs that there is a deep conviction that human life has not only its "length" but also its "weight." When people die and move into another dimension of existence, they stand before the judgment of God. The clock is not the most appropriate model of human life - the hand moves the whole circle, a line that returns to the beginning to once again walk the traveled path. This is death that shows the direction of the timeline, which moves towards its end. Death is an inexorable guardian of the timeline, and directs it to the end. The parable about the rich man and Lazarus, Lk 16:19-31, teaches us that the knowledge of the uniqueness of life is born only on the ground of the divine Word and call; brothers do not

\footnotetext{
${ }^{3}$ Cf. O. Rode, “O śmierci - medycznie, filozoficznie i teologicznie,” Posłannictwo (1977), 3: 25-58; Ch. ChaBAnis, Śmierć, kres czy początek?, trans. A.D. Tuaszyńska (Warszawa: Instytut Wydawniczy PAX, 1987).
} 
listen to Moses and the prophets, they are deaf to the commandments, so they will not be convinced by definitive evidence of the existence of death and of what is after it. ${ }^{4}$

From this perspective, one can better understand the Bible's teaching about the "spheres" of death and its stages. Disease, famine, war, false accusations, persecutions - are already part of the world of death - experiences behind which the power of Sheol is hidden (Ps 18:5-6; Ps 116:3-4; 2-3). The nearness of death can be sensed in every disease and in all kinds of danger. That is why the sick already feel "counted among those who go down to the pit" (Ps 88:4-6), immersed in danger, surrounded as it were by the "waters of death" and entangled in the cords of Sheol (Ps 18:5-6; 69:15-16). ${ }^{5}$

It is only the Christian perspective that opens a new outlook on death and allows us to connect it with hope. The new life that is to come after death is not an extension of the earthly life beyond its limits, into the sphere of afterlife. It is not just a natural transition from one form of life to another, accomplished by the internal law of a given being (like a butterfly hatching from a chrysalis). "What Jesus Christ accomplished and preached is not a necessity of being, but grace. A new existence comes as a gift of God, as His free creative act, but also as fulfillment of man whose secret lies in the fact that ultimately he or she does not exist by law, but thanks to meeting with God and his loving freedom.",

\section{WE BELONG TO CHRIST}

Our existence belongs entirely to Christ: "If we live, we live for the Lord; and if we die, we die for the Lord. So, whether we live or die, we belong to the Lord" (Rom 14:7-8). Life and death are not fully understood unless they are considered in their entirety, with reference to God. Then the right to live does not mean the right of a human being to have a life independent of the Creator, it does not mean the right to die as decided and undertaken by man. The basis of the Christian teaching on death is the resurrection of Christ. "And if Christ has not been raised, our preaching is useless and so is your

\footnotetext{
${ }^{4}$ Cf. W. Stinissen, “Czas i wieczność,” trans. J. Iwaszkiewicz, W drodze (1992), 12 (232): 6-14.

${ }^{5}$ A. Pyтliк, Cierpienia współczesnych Hiobów (Kraków: Wydawnictwo Salwator, 2008), 249-298.

${ }^{6}$ R. GUARDINI, O rzeczach ostatecznych, trans. T. Grodecki (Kraków: Wydawnictwo WAM, 2004), 31.
} 
faith." (1 Cor 15:14). From the resurrection of Jesus, there is hope for individual resurrection of every believer. ${ }^{7}$

The Catechism of the Catholic Church teaches that "Death is the end of earthly life. Our lives are measured by time, in the course of which we change, grow old and, as with all living beings on earth, death seems like the normal end of life. That aspect of death lends urgency to our lives: remembering our mortality helps us realize that we have only a limited time in which to bring our lives to fulfillment" (CCC, No. 1007).

Death is the end of human pilgrimage on the roads of the world, it is also an encounter with Christ - the Lord and the Judge, and the Redeemer; it is reaching out for the gift of a new life.

Theological reflection on the internal structure of death is difficult because it is impossible to place this event in time. The theology of Latin America focused therefore more on the life history to make life a process that leads deliberately to attaining its fullness. After death, man sees "the other side" as a situation which has been completed. There is no mention of the internal structure of death. ${ }^{8}$

The theology of the West is similar when it tries to speak about the "moment of death" (L. Boros, K. Rahner), but leaves the notion blank. Rahner describes death as a process that begins on earth and ends in eternity. He takes the end of worldly life in the form of a timeless point. According to him the end of time is "the innermost moment of death itself." Death only seems to be a continuous process. It has three stages:

1. earthly - does not properly belong to the moment of death but still to life in historical time;

2. the end of time - a real breakthrough;

3. all eternity, if it is timeless or its initial phase, if there is a temporal structure in it (as accepted by W. Kasper, for example). ${ }^{10}$

Lucjan Balter expresses a view that death is a "moment" when man makes the final decision, but he does not explain whether it takes place before or after the critical point. Others are of an opinion that the ultimate decision and death itself as a process that is happening to a person takes place even before the critical point. Others suggest that the dying person has some-

\footnotetext{
${ }^{7}$ L. Boros, Istnienie wyzwolone - rozważania teologiczne. Mysterium mortis - człowiek w obliczu ostatecznej decyzji, trans. B. Białecki (Warszawa: Instytut Wydawniczy PAX, 1985), 90-128.

${ }^{8}$ Cf. J. KożUCHOwski, "Śmierć i umieranie w ujęciu Roberta Spaemanna," Studia Elbląskie (2012), 13: 381-393.

${ }^{9}$ Cf. K. RAhner, V. Vorgrimler, Maty stownik teologiczny (Warszawa, 1987), 449-454.

${ }^{10}$ W. KASPER, "Nadzieja na ostateczne przyjście w chwale," Communio (1987), 2: 32-46.
} 
thing to say after crossing the critical point (e.g. Cz. Bartnik). Still others claim that a particular judgment happens "at the moment of death" of a human being (e.g. T. Mielecki, H. Paprocki), while the "moment" is not a stretch of time, but a point on a timeline. The Orthodox thought departs from treating death as a process that takes place in chronology, before the end point or in a timeless ending point. Death is a dynamic process taking place in some unknown, non-chronological time structure, which is not reduced to one point. ${ }^{11}$

It is a mistake, frequently made by theologians, to accept the materialist concept, which proclaims that the soul is subject to the passing of time in the same way as the human body. According to this concept, death is also the last point of time for the soul, and material time is identical with the current flowing on the spiritual plane. Christian theology accepts, with all obvious ness, the materialistic concept of the human body. The body is material and therefore subject to all laws of the cosmos. The soul is not subjected to them, although it is somehow connected to them. There is no identity, but some analogy, the parallelism between the life of the soul and the body in this world. There is an acceptable hypothesis that, just before death, in the final phase before admission to eternity, this simple bond between the linear time (in which the body moves in its particular space) and the current of soul life is broken. In the pastoral practice of the Church this problem is extremely important, e.g. for the sacramental ministry of the dying. The Church does not administer the sacraments to the dead, and for the living they are a deliverance and a source of redemption. Calling a priest to the house of the sick person is related to the patient's condition: the sacraments cannot be administered to a dead person, it is enough to pray, for it is only prayer that is pos sible. In pastoral practice, if the "death point" is not known, very often even up to a dozen or so minutes after death has been medically recognized - the sacraments are "conditionally" given with a formula "If you live..."12

The fact is that for theology death also remains a mystery. The Pontifical Council Cor Unum, in a document "Questions of Ethics Regarding the Fatally Ill and the Dying" (1981), described the difficulty of adopting a definition of death: "Establishing a medical definition of death is complicated by the fact that at the present state of our knowledge death apparently does not take place all at once. It is not an instantaneous cessation of all the functions of the body, but, rather, a series of cessations of our various life processes, one after the other. It seems that what stops first is the mechanism that regulates

\footnotetext{
${ }^{11}$ L. BAlter, "Nadzieja życia wiecznego,” Communio (1984), 4: 74-94.

${ }^{12}$ P. LISZKA, "Struktura czasowa wydarzenia śmierci,” Horyzonty Wiary (1993), 16: 31-43.
} 
the functioning together of all the organs of the body. This mechanism is situated in the brain. After it stops, necrosis then begins to spread to the various systems: the nervous system, the cardio-vascular, respiratory, digestive, urogenital, and locomotor systems. And last of all, necrosis reaches the cellular and subcellular components. Yet even today, one cannot be too cautious in this matter, for many uncertainties still exist concerning the "medical definition of death."13

In Christian thought death is punishment inflicted by God on the first people for their insubordination. The soul and the body are mortal and immortal at the same time, which is underlined by the concept of "two deaths." St. Augustine talked about the "first" death - the biological death of the body when the soul is separated from the body. It is not good or pleasant for anyone: "For the very violence with which body and soul are wrenched asunder, which in the living had been conjoined and closely intertwined, brings with it a harsh experience, jarring horridly on nature so long as it continues, till there comes a total loss of sensation, which arose from the very interpenetration of spirit and flesh." $"$ This death is the result of the conduct of the first people, is equal to all, and is responsible for the decomposition of the body. "Man, then, is never in life from the moment he dwells in this dying rather than living body." 15

However, all people, according to Christian doctrine, will be raised and will recover their bodies. Then, after the judgment, there may be a "second death," which does not annihilate the body that for some time has been biodegradable, and death is then turning away from God, leading to eternal damnation. Not all will succumb to this death. Righteous life is rewarded with eternal happiness (true life) and wrongful life is punished with existence amidst suffering without God (eternal death, death of the second instance from which there is no return). After the resurrection, the souls and bodies, both of the good and the evil will be eternal. But their de stiny will be different. ${ }^{16}$

\footnotetext{
${ }^{13}$ Questions of Ethics Regarding the Fatally Ill and the Dying, 27 June 1981: http://www.acade miavita.org/_pdf/magisterium/councils/pontifical_council_cor_unum/fatally_ill_and_dying.pdf (July 18, 2017).

${ }^{14}$ St. Augustine, The City of God (Book XIII), 6: http://www.newadvent.org/fathers/ 120113.htm (July 18, 2017).

${ }^{15}$ Ibidem, Book XIII, 10.

${ }^{16}$ N. VAsiliadis, Misterium śmierci, trans. A. Bień (Białystok: Wydawnictwo Bratczyk, 2005), 236-248. Cf. M. PAwliszyn, "Leszka Kołakowskiego kilka uwag na temat śmierci," Studia Elbląskie (2012), 13: 395-404.
} 
Penetration of the structure of death and an attempt to discover its secrets seems to be of little value in comparison with the main task of a human being - to live fully towards good and for eternal happiness. Interest in a "death set," its course and its most accurate depiction can be a deception of the human spirit leading it away from preparations for a meeting with "the One to whom everything belongs..." 17

\section{PREPARING FOR THE MEETING}

The lives of the saints are filled with all sorts of descriptions of canonized people, who with peace and even with hope and joy awaited the time of their death. They are testimony to Christians' deep trust that death is only a transition to a better world. The quoted descriptions of their deaths are meant to strengthen the dying and point to the essence of death as well as direct the mind to what is most important in life.

St. Ignatius, Bishop of Antioch, was offered a possibility to run away and hide from persecution, but he preferred to go to Rome, where he received death sentence by animals in the arena about the year 107. He left behind a letter (The Epistle of Ignatius to the Romans), in which he writes: "Pray, then, do not seek to confer any greater favor upon me than that I be sacrificed to God while the altar is still prepared. [...] Only request in my behalf both inward and outward strength, that I may not only speak, but [truly] will; and that I may not merely be called a Christian, but really be found to be one. [...] I write to the Churches, and impress on them all, that I shall willingly die for God, unless you hinder me. I beseech of you not to show an unseasonable good-will towards me. Allow me to become food for the wild beasts, through whose instrumentality it will be granted me to attain to God. I am the wheat of God, and let me be ground by the teeth of the wild beasts, that I may be found the pure bread of Christ. Rather entice the wild beasts that they may become my tomb, and may leave nothing of my body; so that when I have fallen asleep [in death], I may be no trouble to anyone. May I enjoy the wild beasts that are prepared for me; and I pray they may be found eager to rush upon me, which also I will entice to devour me speedily,

${ }^{17}$ Cf. V. FrankL, Bóg ukryty. W poszukiwaniu ostatecznego sensu, trans. A. Wolnicka (Warszawa: Wydawnictwo Czarna Owca, 2012), 171-192; P. SPORKEn, "Postępowanie z umierającymi," in: Z pomoca umierajacym. Przyczynki do rozmowy na temat umierania i śmierci, trans. S. Szczyrbowski (Warszawa: PAX, 1989), 84-85. 
and not deal with me as with some, whom, out of fear, they have not touched. But if they be unwilling to assail me, I will compel them to do so. Pardon me [in this]: I know what is for my benefit."

St. Francis of Assisi in the Canticle of Creation, wrote, "Be praised, my Lord, for our Sister Death." He treated death not as a nightmare, but as a tool to be freed from the prison of the body and embarrassing bonds of temporality. A victory over death, whose metaphor are bonds, was already announced by St. Luke in his Gospel, in the quote from Saint Peter's sermon on the day of Pentecost: "But God raised him from the dead, freeing him from the agony of death, because it was impossible for death to keep its hold on him." (Acts 2: 23-25).

St. Therese of Lisieux is an example of a Christian perspective on death. She wrote, "I find nothing on earth that makes me happy; my heart is too big, nothing that is called happiness in this world can satisfy it. My mind takes flight to Eternity, time is about to end... My heart is peaceful like a tranquil lake or a serene sky. I do not long for the life of this world, my heart is thirsting for the waters of eternal life!" The daughter of a holy couple Zélie and Louis Martin wrote also: "In a little while my soul will leave the earth, will end its exile, will terminate its combat... I am ascending to heaven... I am touching the homeland, I am carrying off the victory! ... I am about to enter into the abode of the elect, to see beauties that the eye of man has never seen, to listen to harmonies the ear has never heard, to enjoy delights the heart has never tasted... I am a springtime flower that the Master of the garden is plucking for His pleasure."

Another saint, Teresa of Avila, also a Carmelite, wrote a moving hymn about her longing for death: "I live without living in myself, / And in such a way, I hope, / I die because I do not die. [...] Only with that surety / I will die, do I live, / Because in dying / My hope in living is assured. / Death, bringing life, / Do not tarry; I await you, / I die because I do not die."

The "Little Arab," a Palestinian nun, St. Mariam of Jesus Crucified, died at the age of 33 on August 26, 1878 as a Carmelite nun in a monastery in Bethlehem. She said, "My Lord, speed up the moment of my coming to you. I do not like anything on earth. My Lord, please hurry! I do not care about anything now. But if I live, I fear that I'll attach myself to something. I'm afraid of myself ... Oh, gracious death, return me quickly to my Beloved! Yes, you are gracious, you release from prison. To get out of the dark and stand in daylight. I will see my God, the Lord has promised me this." On another occasion, the sisters in the monastery heard her say, "I'm like a fish 
taken out of the water: it opens and closes its mouth, there is no relief. And I am the fish: there is no other relief on earth, but sigh to my homeland. Well! When will the day come? Because here, on earth, everything is passing like lightning, like a flower in a field. [...] Lord, come, come and take my place, and you will see if that is so good. Come and swap places with me... My heart can no longer go like this... And how can I live?" She also said: "I lift my head to the Lord, and when I saw that He does not refuse me anything, I say to Him: Lord, do me a favor, take me quickly!"

Nine years before his death, Padre Pio said he would die at the age of 82 - he died three months after his 82 nd birthday. When, in 1959, a new church was opened in San Giovanni Rotondo, the Capuchin said, "I will die when I dedicate this crypt." And so it happened. When asked if he was afraid of death, he answered firmly, "No!" And he repeated after St. Paul: "For me, to live, is Christ, and to die is gain!"

Similar declarations were made by other saints. Saint Brother Albert Adam Chmielowski - prayed: "Jesus, for your love, I am ready to die." On December 20, 1916, he stayed in Kalatówki, at the foot of the Tatras. He said to the weeping nuns, "I do not want to trouble you with my illness. I will go to Cracow and die there." He indeed went to Cracow and died in a shelter for men on Christmas Day.

In her Diary, St. Faustina Kowalska, also called the Secretary of Mercy, repeatedly mentions a lifebuoy, which was thrown to even the most hardened sinners at the time of death. She wrote about the words she had heard in her soul: "Say unceasingly the Chaplet that I have taught you. Whoever will recite it, they will receive great mercy at the hour of death. Priests will recommend it to sinners as their last hope of salvation. Even if there were a sinner most hardened, if he were to recite this chaplet only once, he would receive grace from My infinite mercy."

St. Augustine expressed the whole truth about "good dying" in the words: "Learn to die well, having learnt to live well. [...] If you are afraid of death, love the resurrection." 18

St. Gregory of Nyssa relates Christological subject of a "deceived deception" to saints. Jesus, by his seeming defeat on the cross, won the battle with Satan. The sick and dying "seemingly" die to live and conquer death. ${ }^{19}$

The Russian writer, Ivan Sergeyevich Turgenev, wrote: "In our country, every peasant dies as though he were performing a solemn rite." The power

\footnotetext{
${ }^{18}$ M. JAKIMOWICZ, "Nie mogę się doczekać," Gość Niedzielny (2015), 44: 18-21.

${ }^{19}$ Grzegorz z Nyssy, "Homilia I in Steph.," in: PG, vol. 46, p. 708 b.
} 
of this rite is sanctifying, and its purpose is to clean one's soul. For one who does not resist death and seemingly surrenders to it, is freed from sin. The soul comes out of him "as if from a purifying bath that cleanses the victims of all sins and stigmas" - as recorded in the Life of Grand Prince St. Andrei Bogolyubsky (1110-1174). ${ }^{20}$

Religious perception of death has room for respect for life, which is God's gift. This awareness generates responsibility for life, which man should accept. Through understanding the source of life, each person is made to "ennoble their consciousness," including those who are dying. Facing the mystery of their life and the mystery of the world they are leaving, they must humbly embrace what is to come. A naive, child-like affirmation of life is no longer sufficient. The problem that remains is how to repay God for His gift, how to transform even the final notes of life into thanksgiving. ${ }^{21}$

\section{TO STRENGTHEN FAITH}

Awaiting the meeting with God is connected with the person's faith. This is faith, in the strict sense of the word, in life "after" the earthly life, life in the "future world." Such life, which is not merely an extension of the familiar existence, is hard to imagine. This existence is different in its essence. Life on earth continues as an endless sequence of successive moments. Eternity is a new dimension of existence, a new quality, a continuous "now." In all contacts with God - in the sacraments, prayer, and meditation - we learn to see Him properly. It is a way of life in eternity already "now," today. Present and eternity do not oppose each other, they do not separate from each other, but they are entangled with each other. Eternal life grows in strength within the time that is given to us. ${ }^{22}$

That is why daily prayer is so important - it builds eternity in man, opens man to God, as well as connects and prepares man for the meeting with the Lord. $^{23}$

\footnotetext{
${ }^{20}$ M. JUGIE, Teologia dogmatica christianorum orientalium, vol. 5 (Roma, 1935), 265. Cf. T. ŚPIDLIK, Życie po śmierci. Maranatha, trans. P. Mikulska (Kraków: Wydawnictwo Salwator, 2009), 91-95.

${ }^{21}$ A. SChweitzer, "Poszanowanie życia," in: IBIDEM, Życie, trans. J. Piechowski (Warszawa, 1971), after: Ethos (1989), 5: 135-136.

${ }^{22}$ J. RAtZinger, "Aby Bóg był wszystkim we wszystkich,” trans. J. Jarco, Znaki Czasu (1992), 28: 3-16.

${ }^{23}$ Cf. A. KoniK-Korn, "Na progu życia wiecznego,” Niedziela (2016), 16: 28-29.
} 
Entire religious care over the dying person is of equally important significance. Every sick person has a right to receive this care, which is also a way of evangelizing illness, a discovery of the redeeming significance of the suffering and pain of passing away. It involves giving a testimony of love through diaconia (service) and canonia (community formation). ${ }^{24}$

The value of suffering is strongly inscribed in Christian teaching. How ever, to discover it, one must refer to the transcendental dimension of humanity - the truth about man's immersion in God. The passion of Christ gave human suffering a new dimension and meaning. Christ does not annihilate suffering, but gives it a new value. Every sick person may become a participant in His Redemption. St. Paul said: "In my body I am filling the shortcomings of Christ's torment for the good of His body, which is the Church" (Col 1:24). ${ }^{25}$

An extremely important role in conveying the Christian truth of suffering befalls the priest. He is a sign of unity with the community of believers, with the Church. He can help the sick live through their suffering in such a way that it brings them closer to Christ, and is used for personal salvation. $\mathrm{He}$ gives hope and peace. With his help, the sick can more easily see the meaning and purpose of their illness. The most important consolation for the sick is eschatological hope. It allows us to see that "our present sufferings are not worth comparing with the glory that will be revealed in us" (Rom 8:18). Everything the Church gives to the sick: the Sacrament of the Anointing of the Sick, the Eucharist, the Confession, the Prayer - opens to them the eschatological perspective. ${ }^{26}$

The Sacrament of the anointing of the sick is a cure of the body and spirit - it illuminates the mysteries of suffering and death, gives hope and opens man to God. In this sacrament man reaches for help in achieving salvation, is strengthened by a new hope and confidence in God, and gains strength to fight temptations and the fear of death. ${ }^{27}$ The sacrament of anointing of the sick is a regular practice of prayer and function of the Church. This is a re-

\footnotetext{
${ }^{24}$ Cf. J. MAKSElon, "Optymalny model poradnictwa psychologiczno-religijnego?," in: Poradnictwo psychologiczno-religijne. Teoria i praktyka, ed. J. Makselon (Kraków: Wydawnictwo Naukowe PAT, 2001), 59-69.

${ }^{25}$ T. SiKORSKI, "Wolność ludzka wobec śmierci," Collectanea Theologica (1987), 3: 26; J. WróBel, Człowiek i medycyna. Teologicznomoralne podstawy ingerencji medycznych (Kraków, 1999), 185-190.

${ }^{26}$ Cf. Katechizm Kościola Katolickiego, no. 1511.

${ }^{27}$ C. KRAKOWIAK, "Sens cierpienia i śmierci w świetle liturgii sakramentu namaszczenia chorych i Wiatyku,” in: Cierpienie i śmierć, ed. A. J. Nowak (Lublin, 1992), 93-96.
} 
sponse to special situations of life and faith, health and misery. The situation of a crisis of faith, existential experience of an ultimate situation, finality and fragility of one's own existence, are a challenge to the spiritual sphere of man. The sacrament brings the answer in the form of a sign. Its reception should be preceded by a conversation and an explanation of its meaning in order to create the right conditions to achieve a better attitude of the patient. Creative faith enables a possibility of recognizing the meaning, which allows the sick person to rise above their own existence and condition. Receiving the sacrament assumes at least habitual (basic) readiness of the sick person to accept it - when there is no current verbal expression of such a wish. Similarly, administering the sacrament to an unconscious person requires a justified habitual willingness to receive it (justified by long-standing faith, prayer or signs of religious behavior of the sick, such as a locket or a cross in the hand - accepted before losing consciousness.) Very often the sacrament of anointing of the sick is received earlier, before the person falls ill, for example during the parish days of the sick, retreat or parish missions, when it is administered to a group in a church or a chapel. ${ }^{28}$

Administering the sacrament of the anointing of the sick can alone bring great spiritual and sometimes physical help. It transmits "the grace of the Holy Spirit, whose internal anointing on the one hand frees the soul of the sick person from sins, and on the other, brings them relief and comfort as well as raises in them great trust in the merciful love of God. In this way, it is easier for the patient to endure all the inconveniences and discomforts associated with illness, and enables them to repel Satan's temptations with greater energy. In addition, sometimes the anointing brings back health to the body when the salvation of the soul demands it." 29

The Eucharist, as Viaticum, gains a new meaning and effectiveness for the dying person. It grants a promise of resurrection, according to the words, "Whoever eats my flesh and drinks my blood has eternal life, and I will raise them up at the last day" (John 6:54). ${ }^{30}$

In religious care, prayer plays an important role, opening the horizons of God's life. It introduces one into the "community of saints" and renews broken relationships. It is natural and even necessary to pray for recovery be-

${ }^{28}$ J. MAYER-SCHEU, A. REINER, "Znak zbawienia dla chorych - namaszczenie chorych dzisiaj," in: Z pomocq umierajacym, 146-162.

${ }^{29}$ JAN PAWE⿺ II, "Namaszczenie chorych. Audiencja generalna, 29 IV 1992,” in: JAN PAWEŁ II, Katechezy Ojca Świętego Jana Pawta II. Kościót (Kraków-Ząbki: Wydawnictwo M, Apostolicum, 1999), 114.

${ }^{30}$ J. TARnAWA, Katecheza o cierpieniu, 203-204. 
cause health is a great gift of God. Recalling this, Pope John Paul II invoked the words of St. Paul (see 1 Thess 5:16). Prayer is help, comfort and strengthening. When a person is weakened, suffering and forgetful, this is prayer that supports a living and real bond with God who, as a Father, loves every person. ${ }^{31}$

The presence of a priest as a representative of the Church is also important from a psychological point of view. The dying person feels safer and accepts suffering more easily. The priest often visits the sick at the request of the patient, a doctor, a nurse, or a family member. When it is the sick person who asks for a priest, the meeting is easier because it is welcome. The problem may arise when the request has been made by a stranger who has not really consulted the sick person. Usually, a priest is called when the patient is directly threatened with death. The visit must then have a fundamental character and refer to the essential elements of the message of salvation, and direct preparation for death. There is no place for unnecessary comforting and remaining under a delusion that health can still improve. The priest comes then to help solve the last life issues and introduce the sick into the area of death. ${ }^{32}$

The presence of a priest in the last moments of the patient's life reminds one of the social nature of death. John Paul II reminded us that participation of the Church in the service of the sick and suffering lies in the very nature of the Church. The Church indeed is not of the world (cf. John 17:16), but according to the message given us by Jesus - she lives and carries out the redemptive work of Christ. ${ }^{33}$

Resurrected Christ defeated Satan and death. It is thanks to His death and resurrection that we may believe that we also will rise from the dead on the last day, and hope for a life in the future world. This promise is exemplified by descriptions of raising the dead - unexpected, wonderful returns from death to life. Christ himself performed them, but also, by the power of God, so did prophets and saints.

\footnotetext{
${ }^{31}$ JAN PAWE⿺ II, "Spotkanie z chorymi w Perugii (Włochy), 26 X 1986," in: JAN PAWEe II, O cierpieniu. Wypowiedzi Ojca Świętego do chorych i pracowników służby zdrowia, ed. M. Kloss, part 3 (1984-1986) (Niepokalanów: Wyd. Ojców Franciszkanów, 1993), 245; JAN PAWE⿺ II, "Spotkanie z chorymi w Callao (Peru), 4 II 1985," in: JAN PAWE⿺ II, Ewangelia cierpienia. Wybór homilii, przemówień i dokumentów (Kraków: Znak, 1997), 93-94.

${ }^{32}$ P. SPORKEN, "Postępowanie z umierającymi," in: Z pomoca umierajacym, 86-100.

${ }^{33}$ JaN PAWEe II, "List apostolski motu proprio 'Dolentium Hominum' ustanawiający Papieska Komisję ds. Duszpasterstwa Służby Zdrowia, 11 II 1985," in: W trosce o życie. Wybrane dokumenty Stolicy Apostolskiej, ed. K. Szczygieł (Tarnów: Wydawnictwo Diecezji Tarnowskiej BIBLOS, 1998), 170.
} 
The Old Testament writes about the raising of the son of the widow of Zarephath by the Prophet Elijah (1 Kings). A similar miracle was made by Elisha, who had prayed for a son for a childless Shunammite family, and then, when he died, returned him to life.

Jesus raised a widow's son in Nain, a daughter of Jair and his friend Lazarus. Jesus also bestowed the power of raising the dead on the apostles. In the Acts of the Apostles two such cases are described: Peter healed Dorcas in Jaffa and raised Eutychus, who had listened to the sermon of St. Paul in Troas, fell asleep and fell from the third floor.

Some of the saints also received the power of raising the dead. Patron saint of France, St. Martin (316-397), was called "trium mortuorum succitator." He raised a pagan child at the request of his mother; a monk from Ligugé, and a young slave who had hanged himself.

Numerous miracles of bringing dead persons back to life were attributed to St. Anthony of Padua (1195-1231), including a girl drowned in a barrel, a child who had died in his sleep, and a murdered young aristocrat, whose body was thrown into the garden belonging to St. Anthony's father, thus bringing an accusation against the latter - Anthony went to his father in Lisbon to raise the man and dismiss the false accusations.

Among the greatest thaumaturges (resurrectors) in the history of the Church we find St. Patrick (hagiography attributes 39 resurrection miracles to him) and St. Vincent Ferrer (28-30 resurrection miracles).

Polish blessed and saints also performed resurrection miracles: a Dominican, St. Hyacinth was believed to have raised about 50 people, B1. Czesław and St. Andrzej Bobola (11 resurrection miracles at his grave). One of the most famous stories is one of St. Stanislaus, Bishop of Cracow and martyr, who brought back to life Piotr, a knight from Janiszew, also called Piotrowin. His resurrection was to confirm the truthfulness of the Bishop as to the payment for the land he had bought from a knight. ${ }^{34}$

Stories of the recovered life bring spiritual comfort, because they remind us of Who life belongs to, Who governs and makes decisions about it. These stories are a prelude to what awaits all who believe and trust the Lord who gave us life and seemingly takes it away so as to make it last forever.

\footnotetext{
${ }^{34}$ Cf. H. BEJDA, “I oczekuję wskrzeszenia umarłych,” Źródło (2009), 15: 10-11.
} 


\section{SELECTED BIBLIOGRAPHY}

BALTER, L. "Nadzieja życia wiecznego.” Communio (1984), 4: 74-94.

BOROS, L. Istnienie wyzwolone - rozważania teologiczne. Mysterium mortis - człowiek w obliczu ostatecznej decyzji, 90-128. Trans. B. Białecki. Warszawa: Instytut Wydawniczy PAX, 1985.

ChabAnis, Ch. Śmierć, kres czy początek? Trans. A.D. Tuaszyńska. Warszawa: Instytut Wydawniczy PAX, 1987.

FrANKL, V. Bóg ukryty. W poszukiwaniu ostatecznego sensu, 171-192. Trans. A. Wolnicka. Warszawa: Wydawnictwo Czarna Owca, 2012.

GrZEGORZ Z Nyssy. "Homilia I in Steph.” In: PG, vol. 46, p. 708 b.

GuARDINI, R. O rzeczach ostatecznych. Trans. T. Grodecki. Kraków: Wydawnictwo WAM, 2004.

HoŁowniA, Sz., KaLb, C. “Wiara i medycyna.” Newsweek Polska (2003), 49: 72-82.

JAKIMOWICZ, M. "Nie mogę się doczekać.” Gość Niedzielny (2015), 44: 18-21.

JugIE, M. Teologia dogmatica christianorum orientalium, vol. 5. Roma, 1935.

KASPER, W. "Nadzieja na ostateczne przyjście w chwale.” Communio (1987), 2: 32-46.

KoniK-Korn, A. "Na progu życia wiecznego.” Niedziela (2016), 16: 28-29.

KożUCHOwsKi, J. "Śmierć i umieranie w ujęciu Roberta Spaemanna.” Studia Elbląskie (2012), 13: 381-393.

LiszKA, P. "Struktura czasowa wydarzenia śmierci.” Horyzonty Wiary (1993), 16: 31-43.

MAKSELON, J. “Optymalny model poradnictwa psychologiczno-religijnego?" In: Poradnictwo psychologiczno-religijne. Teoria i praktyka. Ed. J. Makselon, 59-69. Kraków: Wydawnictwo Naukowe PAT, 2001.

PAWLisZYN, M. "Leszka Kołakowskiego kilka uwag na temat śmierci.” Studia Elblaskie (2012), 13: 395-404.

PytLIK, A. Cierpienia wspótczesnych Hiobów. Kraków: Wydawnictwo Salwator, 2008.

RAHNER, K., VORGRIMLER, V. Mały słownik teologiczny. Warszawa, 1987.

RAtzinger, J. “Aby Bóg był wszystkim we wszystkich.” Trans. J. Jarco. Znaki Czasu (1992), 28: $3-16$.

Rode, O. “O śmierci - medycznie, filozoficznie i teologicznie.” Posłannictwo (1977), 3: 25-58.

SACRED CONGREGATION FOR THE DOCTRINE OF THE FAITH: Letter on Certain Questions Concerning Eschatology, http://www.vatican.va/roman_curia/congregations/cfaith/documents/rc_con_cfaith_ doc_19790517_escatologia_en.html (July 15, 2017).

Schweitzer, A. "Poszanowanie życia.” In: IDEM. Życie. Trans. J. Piechowski. Warszawa, 1971; after: Ethos (1989), 5: 135-136.

SIKORSKI, T. "Wolność ludzka wobec śmierci." Collectanea Theologica (1987), 3.

ŚPIDLIK, T. Życie po śmierci. Maranatha, 91-95. Trans. P. Mikulska. Kraków: Wydawnictwo Salwator, 2009.

SPORKEN, P. "Postępowanie z umierającymi.” In: Z pomoca umierającym. Przyczynki do rozmowy na temat umierania i śmierci, 84-85. Trans. S. Szczyrbowski. Warszawa: PAX, 1989.

ST. Augustine, The City of God (Book XIII), 6: http://www.newadvent.org/fathers/120113.htm (July 18, 2017).

Stinissen, W. “Czas i wieczność.” Trans. J. Iwaszkiewicz. W drodze (1992), 12 (232): 6-14. 
VASILIADIS, N. Misterium śmierci. Trans. A. Bień. Białystok: Wydawnictwo Bratczyk, 2005.

WRÓBEL, J. Człowiek i medycyna. Teologicznomoralne podstawy ingerencji medycznych. Kraków, 1999.

RELIGIJNOŚĆ W KONTEKŚCIE KOŃCA ŻYCIA

\section{STRESZCZENIE}

Oczekiwanie na spotkanie z Bogiem łączy się z osobistą wiarą. Jest to wiara - w ścisłym tego słowa znaczeniu - w życie pozagrobowe, życie w „przyszłym świecie”. Taka egzystencja, nie będąc jedynie przedłużeniem tego co znamy na ziemi, jest trudna do wyobrażenia, bo jej istota jest inna. Życie na ziemi to niekończący się ciąg następujących po sobie chwil, natomiast wieczność jest nowym wymiarem istnienia, nową jakością, ciągłym „teraz”. W każdorazowym kontakcie z Bogiem, odbywającym się w sakramentach, modlitwie i medytacji, uczymy się właściwego spojrzenia na Niego. Jest to życie wieczne, które ma miejsce już „teraz”. Teraźniejszość i wieczność nie stoją w sprzeczności, nie są od siebie odrębne, ale przeplatają się. Życie wieczne umacnia się w czasie, który został nam dany.

Ogół wsparcia religijnego udzielanego osobie umierającej jest równie ważny. Każda chora osoba ma prawo do takiej opieki, która jest sposobem ewangelizowania choroby, odkrywaniem odkupieńczego znaczenia cierpienia i bólu przemijania. Wsparcie religijne polega na dawaniu świadectwa miłości poprzez diakonię (służenie) i kanonię (tworzenie wspólnoty).

Słowa kluczowe: śmierć; przynależność do Chrystusa; przygotowanie, spotkanie. 